\title{
VOLCANIC CENTRES BETWEEN FRIGG FJORD AND MIDTKAP, EASTERN NORTH GREENLAND
}

\author{
Ian Parsons
}

A series of small volcanic centres cut Ordovician turbidites of Formation A in the southern part of Johannes V. Jensen Land between Midtkap and Frigg Fjord (Map 2). Their general location and main rock types were described by Soper et al. (1980) and their nomenclature is adopted here for fig. 22 with the addition of the small pipe B2. A further small intrusion, south-west of Frigg Fjord, was described by Pedersen (1980). The centres lie 5-10 km south of, and parallel to, the important Harder Fjord fault zone (fig. 22) which traverses the southern part of the North Greenland fold belt and shows substantial downthrow to the south (Higgins et al., this report).

All the centres are intrusive breccia bodies which cross-cut the local structure. Although there are deformed blocks within the breccias this deformation occurred prior to incorporation, and post-intrusive deformation is restricted to minor marginal displacements. The intrusions form upstanding crags (illustrated by Soper et al., 1980 fig. 32) surrounded by scree. Exposures of country rock in their vicinity are, in general, too poor to establish whether the regional tectonic pattern has been significantly disturbed by their emplacement, but they seem, certainly, to post-date the main regional deformation which is Devonian early Pennsylvanian (Surlyk et al., 1980).

Blocks in the pipes have interesting, somewhat enigmatic, implications for palaeogeographic reconstructions of North Greenland. They broadly comprise three categories: local sediments, basement metamorphic rocks and associated igneous rocks (not otherwise exposed in Peary Land), and a suite of highly altered basic volcanics, gabbros and serpentinites. Included fragments range in size from several hundreds of metres down to submicroscopic, and the matrix, in some cases, is glass. Extensive zones of sediment around the centres are brecciated and subjected to carbonate- and quartz-veining (fig. 22), and carbonation is common throughout the diatremes, sometimes leading to larger bodies of carbonate-breccia with, superficially at least, the appearance of carbonatite.

\section{Structure and contents of individual centres}

\section{Centre A.}

This is a small, near vertical sheet, outcropping immediately west of the summit of Midtkap, consisting of a $50 \mathrm{~m}$ long, vertical lens of pale granite enclosed by serpentinite and carbonate breccia. Two variants of the granite occur in contact, the darker occurring in places as xenoliths in the lighter, and both are highly brecciated, forming a jostled mass of blocks up to $20 \mathrm{~cm}$ in size in a finely comminuted matrix. The serpentinite encloses the granite, but is more extensively developed on the western side, where it is $100 \mathrm{~m}$ wide. The dark green serpentinites are invariably brecciated and much veined by rusty-weathering carbonates. Interleavings of black carbonate-rock occur. The sheet, as a whole, is clearly discordant to the bedding of the local sedimentary sequence on the east ridge of Midtkap. 


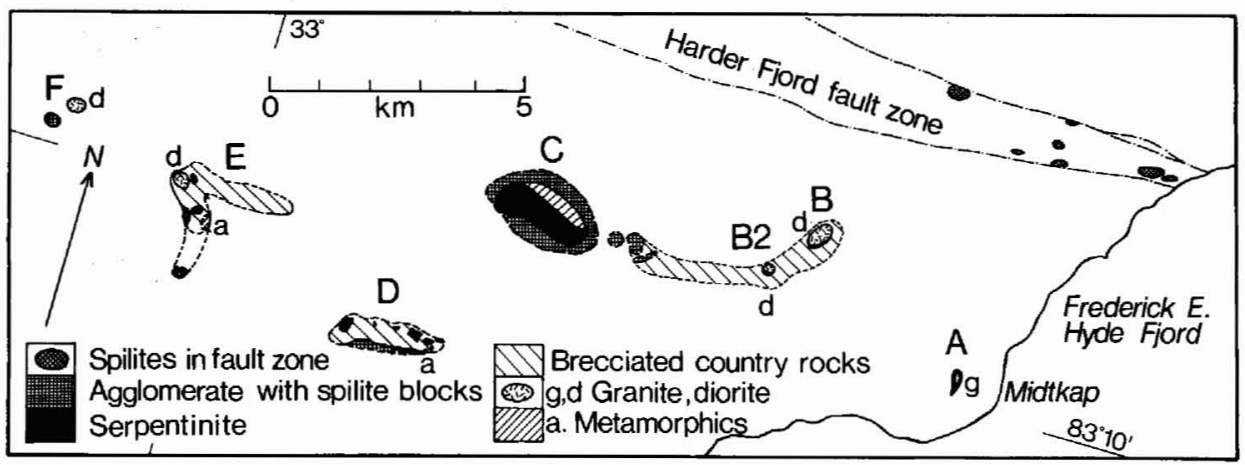

Fig. 22. Map showing the location and contents of the Frigg Fjord diatremes. For regional setting see Map 2 in the back of this report. The ornament shows the main exotic rock type in each centre. Spilite outcrops in the Harder Fjord fault zone are inserted from the maps of A. K. Higgins and N. J. Soper.

The leucocratic granite is a medium grained, quartzose, two-feldspar biotite granite, with patches exhibiting granophyric texture. The darker variant is relatively quartz-poor and distinguished by well-shaped, strongly-zoned plagioclase with a little interstitial alkali feldspar. The rock is a quartz-diorite or tonalite. In both rocks the mafic phases are largely altered to chlorite, but some biotite remains, and feldspars are only slightly turbid in patches. The degree of alteration is on a scale quite normal in basement granites and the volcanic gases associated with the emplacement of the diatremes do not appear to have caused extensive alteration. There is no foliation or banding in these rocks, which appear to be wholly igneous. They presumably represent intrusions into the basement, which therefore contains composite, intrusive, granitic complexes as well as amphibolite-facies, metamorphic rocks (see below).

\section{Centres $B$ and $B 2$.}

These two small elliptical masses are, largely, of fragmented diorite. Both have narrow serpentinite selvages. The diorite is more finely comminuted at the margins but even in the centre of the pipes it is brecciated, with thin veins of fine material ramifying through a packed mass of angular blocks. Country rocks (largely mudstones) are brecciated in the vicinity of the centres which, from steep outcrops at the western end of $B$, clearly have vertical boundaries. On the northern edge of $\mathbf{B}$, the diorite breccia abuts directly on hardened and bleached mudstones, but at the western end, a $1 \mathrm{~m}$ zone of cleaved diorite intervenes at the contact with carbonate-veined mudstone. This vertical shearing also affects the 20-30 m wide selvage of serpentinite which forms a rim to the diorite south of this point.

The larger fragments in the more highly brecciated rocks are almost entirely plagioclase (calcic andesine from optics), somewhat sericitized, and frequently bent and fractured. A few groups of feldspars occur, which preserve the texture of the original igneous rock, but despite their compact appearance in hand specimen, many large fragments are really composed of crystals separated from one another by finely comminuted material, which gives the appearance of a crystal-tuff. In places, this has recrystallized to a mosaic of small, rounded granules, but elsewhere, although more crystalline material is present than is immediately evident under low-power, some of the matrix is glass, yellowish in colour, with moderate 
refractive index $(1.594 \pm 0.002)$. Patches of carbonate and veins of clear albite occur in the matrix, and in places quartz. Euhedral grains of albite and calcite are found in lined vesicles. Mafic silicates in these rocks are entirely altered to green chlorite.

A zone of brecciation of country rock extends from centre B, via centre B2, to centre C (fig. 22). There are small serpentinite bodies in this zone, and breccias containing the volcanic types found in the outer zone of $\mathrm{C}$.

\section{Centre C.}

This is the largest centre, some $2 \mathrm{~km}$ in length, which forms a conspicuous, approximately $1000 \mathrm{~m}$ hill with twin summits. The central core is largely serpentinite in contact with a large mass of basement metamorphic rocks, and these rock types are surrounded by a rim of agglomerate largely composed of blue-green, fine-grained volcanic rocks (fig. 22). The agglomerate is for the most part highly fragmented but contains blocks of up to $1 \mathrm{~m}$ across. This volcanic rock type occurs in several of the other centres, and is usually altered to chlorite in radiating groups. When found relatively fresh the chlorite is seen to be replacing stellate plagioclase laths. Veins of clear albite and carbonate occur. The material matches closely, in thin section appearance, material from pillow-lavas collected from the Harder Fjord fault zone (fig. 22) by N. J. Soper and A. K. Higgins in 1979. Indeed, some large fragments in the centre $\mathrm{C}$ agglomerates have a distinctive pillow-like shape, with radial fractures and concentric colour-shading.

Accompanying these spilites in the agglomerates there are lumps of a medium-grained, highly altered gabbro, in which plagioclase is almost wholly replaced. There are larger screens of a fine-grained, flinty rock, originally thought to be of an acid volcanic rock, but which, from X-ray work, appears to be composed mainly of quartz and, therefore, is probably highly indurated sediment. However, interleaved with serpentinite in the core of the complex there are vertical screens of a fine-grained cream-coloured rock, highly altered but at least partly glassy; this contains a number of spherical structures reminiscent of those in spherulitic rhyolite.

Serpentinite covers an area some $1.5 \times 1 \mathrm{~km}$, which is enclosed by a continuous agglomerate ring. These predominantly dark green rocks always show evidence of shearing, with many slickensided surfaces causing breakdown into fine scree which obscures most internal structures. As well as the interleaved leucocratic rocks noted above, there are some areas of a dark green fragmental rock in the serpentinites which are brecciated amphibolite, and vein networks of asbestiform minerals also occur.

Along their north-eastern edge the serpentinites are in sharp, near vertical contact with a large mass of brecciated basement metamorphic rocks, mostly amphibolite. The serpentinite at the junction is sheared, but not notably more so than the main mass of serpentinite, and the amphibolites are brecciated with ramifying veins, a few centimetres across, of fine-grained material with fine lamination which flows round the blocks. Individual blocks may be large $(>10 \mathrm{~m})$. The whole north-eastern section of this centre, therefore, consists of a tightly packed mass of these metamorphic rocks enclosed in a texturally more variable, more obviously agglomeratic, outer ring. Metamorphic rock-types found include amphibolites, amphibole-epidote rocks, feldspathic amphibolite gneiss, acid gneisses and garnet-mica schists. The rocks are very fresh, without secondary alteration in the larger fragments, while finely comminuted material may show development of secondary epidote and chlorite. Even fragments of hornblendic gneiss as small as $2 \mathrm{~mm}$ across seem to preserve their original 
mineralogy and textures. Plagioclase feldspar is perfectly fresh, in striking contrast to spilitic inclusions in the adjacent agglomerates. Pegmatitic segregations in the acid gneisses can in places contain a little superficial malachite.

At the eastern end of the centre there are a number of small satellite bodies of carbonate breccia, serpentinite, and spilite-agglomerate, which link with the B centres through a zone of brecciation.

\section{Centre D.}

This intrusion consists of separate vertical screens of serpentinite in an oval zone of breccia and agglomerate. Serpentinite is intimately interleaved with sediment, particularly bands of black shale and chert. In places the serpentinite encloses $0.5 \mathrm{~m}$ pillow-shaped lenses of black carbonate rock forming loose horizons, and there is extensive carbonate veining. Larger bodies of carbonate form knolls at the eastern end of the complex. These are brecciated quartz-carbonate rocks, perhaps initially non-metamorphic sediments, but in this centre both they and some serpentinites contain rare crystals of a brown chrome spinel, in places somewhat fragmented. Two masses of brecciated amphibolite gneiss were found near the southern margin, and the $200 \mathrm{~m}$ cliffs bounding the southern edge (Soper et al., 1980, fig. 42) consist of a mass of agglomerate of the blue spilitic type found in centre C. A common, superficially porphyritic type of material appears to consist of large fractured plagioclases (andesine), up to $1 \mathrm{~cm}$ in length, together with fragments of spilite, set in a finely comminuted matrix, an intimate mixture of material of plutonic and volcanic igneous parentage.

\section{Centre E.}

Like the B centres, this is a pipe filled with tightly packed diorite or gabbro blocks, some showing evidence of deformation prior to inclusion in the breccia. Paler, more acid fragments also occur together with a porphyritic quartz-bearing hypabyssal rock. The fine-grained green-coloured breccia which forms much of the eastern part of this centre is pulverized amphibolite. In this centre, unlike in B, the serpentinite does not form a selvage at the contact, but occurs as two isolated bodies enclosed in breccia. Irregular zones of brecciation and carbonate veining extend east and south of the main bodies.

\section{Centre $F$.}

This comprises two small pipes, the most northerly filled with tightly packed brecciated diorite, the other with agglomerate of spilitic fragments. These show the albite- and carbonate-veining also seen in centre $\mathrm{C}$, and some fine grained sedimentary material is also present. 


\section{Discussion}

\section{General structural relationships}

All the centres are discordant volcanic pipes and the rocks filling them are intensely brecciated. Brecciation is least intense in B and B2 where there is a selvage of serpentinite between the igneous breccia and country rocks. Brecciation is least pronounced in the centre of these pipes. All the pipes consist of tightly packed masses of blocks, but some have outer sections of more highly fragmented agglomerate. There are signs that some block material in these agglomerates was deformed and recrystallized prior to brecciation, but the comminuted material is not foliated, except where it shows a flow-foliation around blocks and demonstrable post-emplacement deformation is restricted to the cleavage as seen at the margin of B. Pedersen (1980) suggests that the Midtkap serpentinite (intrusion A) has been involved in the regional thrusting and folding, but the serpentinite bodies in the larger centres (C and D) are strongly slickensided even though enclosed in undeformed agglomerate. The serpentinites thus seem to have been deformed prior to incorporation in the intrusive centres, which themselves post-date the main regional tectonism.

The emplacement of the pipes appears to have been extremely violent, leading to fine scale fragmentation of rocks of all types. Temperatures evidently were high enough to cause fusion of matrix, producing glass. However, gases accompanying this activity were either unreactive, or more probably were not present for long enough to cause extensive alteration of included basement rocks. Once-and-for-all explosive emplacement seems implied.

\section{Contents of the pipes}

Recognizable, exotic, block material in the pipes falls broadly into two categories: a suite of fresh basement metamorphic rocks together with plutonic igneous rocks, and a suite of highly altered basic volcanic rocks, gabbros and serpentinites.

The basement suite comprises amphibolite facies metamorphics and plutonic granitic to dioritic types consistent with the presence of post-tectonic composite igneous bodies in the basement. As noted by Soper et al. (1980), the Proterozoic - Lower Palaeozoic depositional basin in North Greenland was ensialic, even though close to a continental margin.

Apart from the intense brecciation these basement rocks are strikingly fresh, which is in considerable contrast to the altered basic volcanics. The latter rock, with its variolitic texture, albite- and carbonate-veining is common to three centres, and is associated with highly altered gabbros. Feldspar, very fresh in the 'basement' suite, is almost completely replaced in this basic assemblage. This strongly suggests that the alteration of the basic rocks occurred prior to their incorporation in the pipes; the diatremes brought up xenoliths of already altered lithologies. A third member of this assemblage is serpentinite, intimately associated with shales, black limestones and chert horizons. The serpentinites occur in two settings: as narrow selvages to breccia-filled pipes or as large included bodies. This is a curious dual role which perhaps suggests that two types of serpentinite are present, some being locally derived metasomatic rocks. It is intended to provide chemical data on this topic in a later report.

The similarity of the basic volcanic types to spilites, in particular to those near the Harder Fjord fault zone, has already been noted. The assemblage of spilites, altered gabbros, serpentinites, black shales and cherts immediately suggests an ocean floor environment, and 
two possible scenarios are suggested here. The correlation with the Harder Fjord fault zone spilites, if correct, implies that an extensive belt of these rocks at least $10 \mathrm{~km}$ wide and extending some $60 \mathrm{~km}$ west towards Drengs Bræ (Map 2) was, or is, present in southern Johannes V. Jensen Land. A small area of greenstone east of Depotbugt (Map 2), $80 \mathrm{~km}$ east of Midtkap, reported by Higgins et al. (this report), may also conceivably be related to the occurrences described here.

In the Harder Fjord fault zone the spilites are in a zone of complexity which includes Permian and Cretaceous sediments. It is possible that they are of similar age, and that they therefore represent downfaulted remnants of an extensive spilite cover. This hypothesis requires that the volcanic centres contain an intimate mixture of material carried up from depth (basement rocks) and fall-back material from above (the spilite assemblage).

A more plausible hypothesis is that the spilite-serpentinite assemblage is an otherwise unexposed, marginal, ocean-floor assemblage in the turbidite sequences beneath the Frigg Fjord mudstones. Some support for this highly speculative idea comes from a sample of Formation A conglomerate collected in situ $1 \mathrm{~km}$ north of centre E. This contains abundant volcanic fragments, both of relatively fresh basaltic types, and also of highly altered material remarkably like the described spilites. Also Fränkl (1955) refers, enigmatically, (pp. 40 and 59), to '?volcanic bombs' in the Frigg Fjord mudstones. Volcanic rocks similar to those in the breccia pipes were undoubtedly available as a sediment source in Lower Ordovician times. The association of spilites with Permian and younger rocks in the fault zone may therefore be fortuitous and A. K. Higgins (personal communication, 1981) has suggested that these volcanic outcrops too could be interpreted as individual diatremes.

The Harder Fjord fault zone apparently has a long history of movement extending up to Tertiary times, when its effect was of downthrow to the south. The history of the fault during the Lower Palaeozoic is uncertain (Higgins et al., this report). Surlyk et al. (1980) visualize it as one of a series of faults bounding the marginal limestone platform sequences of Peary Land, to the south, and forming the southern limit of an east-west clastic trough later deformed to give the North Greenland fold belt. It could be that sub-marine volcanicity accompanied turbidite deposition in the vicinity of the trough-bounding fault and that these volcanic rocks, otherwise unexposed, like the basement gneisses, have been later brought up as xenoliths in the volcanic rocks.

\section{Age of the centres}

The most likely age correlation for the emplacement of these pipes is with the alkaline Kap Washington Group volcanic rocks $70 \mathrm{~km}$ to the north-west (Brown \& Parsons, this report). Non-fragmental rocks directly attributable to the volcanism are absent from the pipes, however, and apart from the gas-charged and obviously explosive nature of the volcanicity there are no characteristics which particularly indicate alkaline affinities. The carbonate bodies are quartz-carbonate rocks, probably mobilized sediment rather than carbonatite, and there is no evidence of alkali metasomatism. If the spilite material in the Harder Fjord fault zone is in the form of diatremes which cut rocks as young as Cretaceous, then the Kap Washington Group correlation seems highly plausible. However, if the association in the fault zone is a faulted relationship, or if the correlation of these rocks with the volcanic centres between Frigg Fjord and Midtkap is incorrect, then the latter could be 
considerably older, restricted only by the Devonian to Carboniferous age of the deformation affecting the turbidites that they cut.

\section{References}

Fränkl, E. 1955: Rapport über die Durchquerung von Nord Peary Land (Nordgrönland) in Sommer 1953. Meddr Grønland 103(8), 61 pp.

Pedersen, S. A. S. 1980: Regional geology and thrust fault tectonics in the southern part of the North Greenland fold belt, North Peary Land. Rapp. Grønlands geol. Unders. 99, 79-87.

Soper, N. J., Higgins, A. K. \& Friderichsen, J. D. 1980: The North Greenland fold belt in eastern Johannes V. Jensen Land. Rapp. Grønlands geol. Unders. 99, 89-98.

Surlyk, F., Hurst, J. M. \& Bjerreskov, M. 1980: First age-diagnostic fossils from the central part of the North Greenland foldbelt. Nature 286, 800-803. 